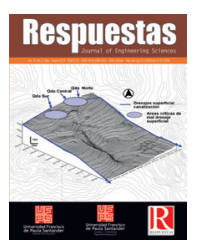

Original Article

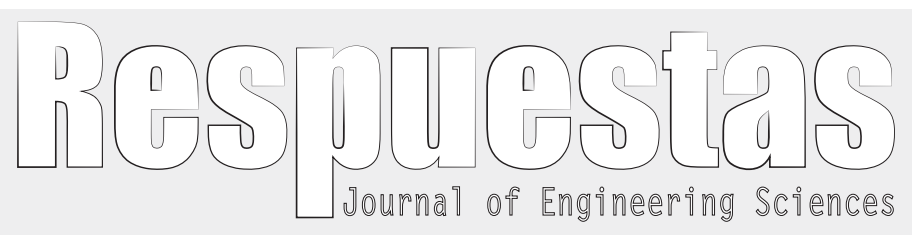

https://doi.org/10.22463/0122820X.1828

\title{
Chemical and thermal characterization of the construction material of nests of seven species of wasps from Norte de Santander - Colombia
}

Caracterización química y térmica del material de construcción de nidos de siete especies de avispas del Norte de Santander - Colombia

María Del Carmen Parra-Hernández ${ }^{1}$, Diana Alexandra-Torres Sánchez ${ }^{2 *}$

${ }^{1}$ Chemistry, maria.parra6@unipamplona.edu.co, ORCID: 0000-0003-2034-4495, Universidad de Pamplona, Pamplona, Colombia

${ }^{2 *}$ PhD in Chemistry Sciences, datorres@unipamplona.edu.co, ORCID: 0000-0002-0602-9299, Universidad de Pamplona, Pamplona, Colombia.

How to cite: M.C. Parra-Hernadez y D.A. Torres-Sanchez, "Chemical and thermal characterization of the construction material of nests of seven species of wasps from Norte de Santander - Colombia”. Respuestas, vol. 24, no. 2, pp. 26-36, 2019.

Received on August 09, 2018; Approved on November 10, 2018

\begin{tabular}{|c|c|}
\hline & CT \\
\hline $\begin{array}{l}\text { Keywords: } \\
\text { Wasps, } \\
\text { Nests, } \\
\text { Thermogravimetric } \\
\text { Analysis (TGA), } \\
\text { Differential } \\
\text { Scanning } \\
\text { Calorimetry } \\
\text { (DSC), } \\
\text { Fourier Transform } \\
\text { Infrared } \\
\text { Spectroscopy } \\
\text { (FTIR), } \\
\text { X-ray } \\
\text { Fluorescence } \\
\text { (XRF). }\end{array}$ & $\begin{array}{l}\text { Social wasps are insects that construct their nests using wood pulp, plant and themselves secretions for the } \\
\text { accomplishment of their activities as a colony. Currently in Colombia, there is little knowledge about this } \\
\text { interesting material due to its characteristics, which could be used in promising applications. In this work } \\
\text { the chemical and thermal characterization of nests of seven species of wasps (Agelaia pallipes, Agelaia } \\
\text { multipicta, Agelaia areata, Polybia aequatorialis, Parachartergus apicalis, Mischucytharus imitator, } \\
\text { Brachygastra lecheguana) living in Norte de Santander, was carried out with the purpose of establishing } \\
\text { if there are significant differences between species and provide information that could be used as a model } \\
\text { or precursors for the synthesis in biomimetics and / or nanotechnology. Thermogravimetric analysis (TGA) } \\
\text { and differential scanning calorimetry (DSC) were performed using a Thermal analyser SDT-Q600 from T.A. } \\
\text { Instruments. An infrared spectrophotometer FT-IR SHIMADZU Prestige-21 with ATR was used for infrared } \\
\text { analysis. The fluorescence analysis (XRF) was performed using a sequential X-ray fluorescence spectrometer } \\
\text { of dispersive wavelength of } 4 \mathrm{~kW} \text { BRUKER model S8 TIGER. The thermogravimetric analysis shows } \\
\text { three mass losses and four degradation processes related to moisture loss, degradation of hemicellulose, } \\
\text { cellulose and lignin. The infrared analysis allowed identifying characteristic functional groups of cellulose, } \\
\text { hemicellulose and lignin. Through the X-ray fluorescence analysis, some metals such as K, Ca, Al, Mg, } \\
\text { Ti, Cr, Mn, Fe, Ni, Cu, Zn, Se and Li were found. The analyses made of the samples allowed to establish } \\
\text { differences and similarities in the construction material of the studied species. }\end{array}$ \\
\hline
\end{tabular}

\section{RESUMEN}

\section{Palabras clave:}

Avispas,

Nidos,

Análisis

Termogravimétrico

(TGA),

Calorimetría

Diferencial de

barrido (DSC),

Espectrofotometría

Infrarroja (FTIR),

Fluorescencia de

Rayos x (XRF).
Las avispas sociales son insectos que construyen sus nidos utilizando pulpa de madera, secreciones de plantas y de diferentes partes de su cuerpo que requieren para la realización y ejecución de sus actividades como colonia. Actualmente en Colombia se tiene poco conocimiento acerca de este material que podría aprovecharse en diferentes aplicaciones. En el presente trabajo se realizó la caracterización química y térmica de nidos de siete especies de avispas (Agelaia pallipes, Agelaia multipicta, Agelaia areata, Polybia aequatorialis, Parachartergus apicalis, Mischucytharus imitator, Brachygastra lecheguana) de Norte de Santander con motivos de establecer si existen diferencias significativas entre especies y proporcionar información que sea la base de otras investigaciones encaminadas hacia la utilización de estos materiales como modelos o precursores de síntesis en biomimética y/o nanotecnología. Los análisis termogravimétrico (TGA) y calorimetría diferencial de barrido (DSC) se realizaron empleando un equipo SDT-Q600 de T.A. Instruments. Para el análisis infrarrojo se utilizó un espectrofotómetro infrarrojo FT-IR SHIMADZU Prestige-21 con ATR. El análisis de fluorescencia (XRF) se realizó empleando un espectrómetro secuencial de fluorescencia de rayos $\mathrm{X}$ de longitud de onda dispersiva de 4kW marca BRUKER modelo S8 TIGER. En el análisis termogravimétrico se encontraron tres pérdidas de masa y cuatro procesos de degradación

*Corresponding author.

E-mail address: datorres@unipamplona.edu.co (Diana Alexandra Torres Sánchez)

(c) $($ (1) $\Theta$ Peer review is the responsibility of the Universidad Francisco de Paula Santander.

cc) 
relacionados con la pérdida de humedad, la degradación de hemicelulosa, celulosa y lignina. El análisis infrarrojo permitió determinar grupos funcionales característicos de celulosa, hemicelulosa y lignina. A través del análisis de fluorescencia de rayos $\mathrm{X}$, se detectaron los metales $\mathrm{K}, \mathrm{Ca}, \mathrm{Al}, \mathrm{Mg}, \mathrm{Ti}, \mathrm{Cr}, \mathrm{Mn}, \mathrm{Fe}, \mathrm{Ni}$, $\mathrm{Cu}, \mathrm{Zn}$, Se y Li. Los análisis realizados permitieron establecer diferencias y similitudes en el material de construcción de las diferentes especies.

\section{Introduction}

Wasps are insects of the order of hymenoptera and suborder apocrite [1], [2]. Hymenoptera are one of the richest metazoan orders on the planet with about 115,000 to 199,000 species described [3] [6]. Wasps are important within tropical ecosystems because they are insects used in biogeographic and ecological studies, as potential biological control agents, in comprehensive studies involving other zoological and floristic groups, and as bioindicators of regional ecological conditions.

Biologically, they are characterized by building collective nests made of chewed wood pulp. The social wasps are organized in three castes, the reproductive females (queens) in charge of laying eggs, the sterile females (workers) and the males. Once they have built their nests, by chewing wood fibers, they deposit their eggs in compartments or cells, where they develop into larvae and pupae, emerging as adults [7], [8]. In temperate regions, a colony lasts only one season: queens being paired hibernate for about 90 days to emerge in spring and form new colonies; workers live for short periods of time, while males generally die after fertilizing the queen [9].

According to nesting sites, ethno-species build their nests on three types of substrates: constructions, terrestrial and vegetal or arboreal. The first refers to sites and materials of anthropogenic origin [10]. Terrestrial substrate refers to natural cavities or abandoned animal cavities, and plant substrate includes weeds, shrubs, leaves, tree branches and hollow trunks [11], the latter being used by most ethno-species for the establishment of their colonies. In the nests, several central activities of the colony occur, such as the reuse of breeding cells, care of immatures until the emergence in adults, provision of chewed prey for their offspring, trophylaxis and reproductive time division of labor [5], [12], [13].
The way in which the nests are built and the characteristics of the material needed to do so highlight the interest of these social insects as models for different human needs, especially for bioclimatic architectural designs and the design of new materials [14]. Currently, the air circulation system in wasp and termite nests is being applied in the optimization of energy consumption in different human constructions [12].

In recent years, biomimetics has been inspired by biological designs, consisting of the imitation of forms and processes of nature, which can be copied to sustainably and effectively improve the design of different processes and services required by humans [15], [16]. In addition, bioengineering and biotechnology have taken advantage of many biological models to understand and solve problems that may be related to food production, pharmaceuticals, and the health of human beings and animals [17]; in the field of health, in the creation of nanoparticles for biomedical purposes [18].

This study was carried out for the purpose of chemically and thermally characterizing the nests built by seven species of wasps from Norte de Santander, Colombia, and to establish whether there are significant differences between species and to provide information to serve as the basis for other research aimed at the use of these materials in different applications.

\section{Materials and methods}

\section{Sampling}

Nest samples of wasp species were collected in different municipalities of the department of Norte de Santander; Agelaia pallipes, Parachartergus apicalis and Mischucytharus imitator (Pamplonita), Agelaia multipicta (Carmen de Tonchala), Agelaia areata and Polybia aequatorialis (Cúcuta). Abandoned 
nests were collected and stored in airtight plastic bags during transport from the collection site to the laboratory.

The identification of the wasp species was carried out by an expert, who examined adult specimens by means of observations under the stereomicroscope at $10 \mathrm{X}$ and $30 \mathrm{X}$ taking into account the morphological identification keys for them.

\section{Instruments, materials and reagents}

For the present study we used a SDT Q-600 thermal analyser from TA Instruments, an FT-IR SHIMADZU Prestige-21 infrared spectrometer with ATR and a $4 \mathrm{~kW}$ dispersive wavelength X-ray fluorescence sequential spectrometer BRUKER model S8 TIGER.

\section{Thermal analysis DSC - TGA}

Thermoanalytic determinations were performed using TA Instruments' SDT Q-600 thermal analyzer which simultaneously performs thermogravimetric analysis (TGA) and differential scanning calorimetry (DSC). The analysis was performed using between 10-20 mg of pulverized sample, and it was introduced in an alumina cell. The analysis parameters were: heating ramp of $10{ }^{\circ} \mathrm{C} / \mathrm{min}$, from ambient temperature $\sim 20{ }^{\circ} \mathrm{C}$ to $700{ }^{\circ} \mathrm{C}$ in nitrogen atmosphere with a flow of $100 \mathrm{~mL} / \mathrm{min}$.

\section{Fourier transform infrared spectroscopy (FTIR)}

A SHIMADZU IR Prestige-2.1 infrared spectrophotometer was used using the attenuated total reflection (ATR) technique, the spectra were obtained in the mid-infrared region, at wavelengths of 600 to $4000 \mathrm{~cm}^{-1}$, with a total of 40 scans and a resolution of $4 \mathrm{~cm}^{-1}$.

\section{$X$-ray fluorescence (XRF)}

The XRF analysis was performed using the QUANTEXPRESS method (fundamental parameters) in the sodium $(\mathrm{Na})$ to uranium $(\mathrm{U})$ range, in a $4 \mathrm{~kW}$ dispersive wavelength X-ray fluorescence sequential spectrometer BRUKER model S8 TIGER. To detect the heavy elements a Scintillation detector was used and for the light elements a flow detector, the X-ray source was a Rhodium tube $(\mathrm{Rh})$ and the high precision goniometer used for theta and 2 theta angles.

\section{Statistical analysis}

Thermal properties were determined using Universal Analysis 2000 software (T.A. Instruments, Delaware, USA). The results of the thermal analysis were analyzed with the statistical package of the program Origin pro evaluation version and the statistical software XLSTAT for Microsoft Excel trial version. Variance analysis (ANOVA) was used to find if there were significant differences between the different values obtained.

\section{Results and analysis}

\section{Thermogravimetry (TGA)}

By means of thermogravimetric analysis (TGA DTG) four mass loss processes were determined in

Table I. Termogravimeter Analysis Results

\begin{tabular}{|l|c|c|c|c|}
\hline \multicolumn{1}{|c|}{ SPECIES } & $\mathbf{T}_{\mathbf{1}}\left({ }^{\circ} \mathbf{C}\right)$ & $\mathbf{T}_{2}\left({ }^{\circ} \mathbf{C}\right)$ & $\mathbf{T}_{3}\left({ }^{\circ} \mathbf{C}\right)$ & Loss of mass (\%) \\
\hline A. pallipes & $224,06 \pm 1,54$ & $306,02 \pm 8,12$ & $350,95 \pm 8,15$ & $81,80 \pm 2,65$ \\
\hline A. multipicta & $216,64 \pm 2,05$ & $297,24 \pm 4,65$ & $323,80 \pm 7,45$ & $69,81 \pm 3,42$ \\
\hline A. areata & $238,58 \pm 1,80$ & $309,39 \pm 1,23$ & $338,63 \pm 4,95$ & $59,33 \pm 7,34$ \\
\hline P. aequatorialis & $224,06 \pm 3,45$ & $305,49 \pm 2,45$ & $341,48 \pm 0,98$ & $68,26 \pm 3,45$ \\
\hline P. apicalis & $215,22 \pm 2,54$ & $298,79 \pm 3,59$ & $322,22 \pm 0,34$ & $68,23 \pm 1,23$ \\
\hline M. imitator & $200,39 \pm 2,34$ & $287,44 \pm 2,87$ & $319,66 \pm 2,01$ & $80,02 \pm 9,45$ \\
\hline B. lecheguana & $229,36 \pm 7,56$ & $307,10 \pm 4,65$ & $345,83 \pm 0,54$ & $84,43 \pm 1,76$ \\
\hline
\end{tabular}


the samples (Figure 1) of the different species. Table I presents the results of the temperatures involved and the percentage of mass loss in each one.

According to Figure 1, initially there was a loss of mass between $50.32 \pm 0.84{ }^{\circ} \mathrm{C}$ and $87.45 \pm 6.74{ }^{\circ} \mathrm{C}$ attributed to the loss of water in the form of moisture absorbed at the surface of the nest, in addition to this there were three other processes of loss of mass. The first $\mathrm{T} 1$ at $200.39 \pm 2.34{ }^{\circ} \mathrm{C}-238.58 \pm 1.80{ }^{\circ} \mathrm{C}$ attributed to the decomposition of hemicelluloses [19]. Statistical analysis reveals that significant differences occur between the nests of the species $A$. areata with the nests of the species $M$. imitator, as well as for the samples of the species $A$. areata with the samples of $P$. apicalis, the samples of $B$. lecheguana with the samples of $M$. imitator, the samples of $P$. aequatorialis with the samples $M$. imitator, A. multipicta with the samples of M. imitator corroborating in this way, that the differences found in the chemical profile of the nests of the different species is directly related to the chewing process of the vegetable material used and the mixture that the wasps add through oral secretions when building the nests [20]. Studies such as that of M.R. Cole [21], in the nests of three species of social wasps (Vespinae), affirm that the choice of type of plant material, plant fibers and the duration of chewing of the materials affects the physical and chemical characteristics of the construction material of the nest. Kazuyiki Kudo [22], in his study states that oral secretions physically protect the nest from the elements and the processing of the pulp is an aspect that could affect the absorption capacity of the nest paper and its durability. Also, the study by Khalid Khan [23], found that the architectural pattern of the nest and the chemical composition vary among different species depending on aspects such as salivary secretions that these insects add to the material, environmental factors and material selection.

On the other hand, studies such as that of W.J. Etges [24], agree that although the place of nesting can influence the composition and thermal behaviour of the nest material, other aspects such as the environment in which wasp colonies carry out nesting and other factors not only genetic, but also exogenous (climate, rain, heat, cold, humidity, among others) must be considered.

The second process, whose mass loss temperature T2 $\left({ }^{\circ} \mathrm{C}\right)$ occurs from $287.44 \pm 2.87{ }^{\circ} \mathrm{C}$ to 309.99 $\pm 1.23{ }^{\circ} \mathrm{C}$ corresponds to the shoulder present in the DTG curve and is associated with cellulose decomposition; the lowest values were identified in the $\mathrm{M}$ species samples. imitator with $287.44 \pm$ $2.87^{\circ} \mathrm{C}$, A. multipicta with $297.24 \pm 4.65^{\circ} \mathrm{C}$ and $P$. apicalis with $298.79 \pm 3.59^{\circ} \mathrm{C}$, the samples of the species recording the highest temperature for this peak were $A$. areata with $309.39 \pm 1.23^{\circ} \mathrm{C}, B$. lecheguana with $307.10 \pm 4.65^{\circ} \mathrm{C}$ and $A$. pallipes with $306.02 \pm 8.12^{\circ} \mathrm{C}$. The samples of the species recording the highest temperature for this peak were A. areata with $309.39 \pm 1.23^{\circ} \mathrm{C}, B$. lecheguana with $307.10 \pm 4.65^{\circ} \mathrm{C}$ and $A$. pallipes with 306.02 $\pm 8.12^{\circ} \mathrm{C}$. For this loss of mass there were no statistically significant differences between the nest samples according to the Bonferroni test.

The third process related to temperature $\mathrm{T} 3\left({ }^{\circ} \mathrm{C}\right)$, occurs from $319.66 \pm 2.01{ }^{\circ} \mathrm{C}$ to $350.95 \pm 8.15^{\circ} \mathrm{C}$, corresponds to the decomposition of lignin. The lowest temperature for this peak occurred in the nests of the species $M$. imitator with $319.66 \pm 2.01{ }^{\circ} \mathrm{C}$, P. apicalis with $322.22 \pm 0.34{ }^{\circ} \mathrm{C}$ and A. multipicta with $323.80 \pm 7.45{ }^{\circ} \mathrm{C}$, the samples that registered the highest value were the nests of $A$. pallipes with $350.95 \pm 8.15^{\circ} \mathrm{C}$ and $B$. lecheguana with $345.83 \pm$ $0.54{ }^{\circ} \mathrm{C}$. Likewise, the analysis of variance reveals that the samples that present significant differences are: the nest samples of the species $A$. pallipes with the nest samples of the species $P$. apicalis, samples that were collected in the municipality of Pamplona. There are also differences between $A$. pallipes with A. multipicta and B. lecheguana with P. apicalis.

According to the degradation temperatures recorded in the nest samples, the samples with the lowest value of $\mathrm{T} 1\left({ }^{\circ} \mathrm{C}\right)$ were the species $M$. imitator, $P$. apicalis and $A$. multipicta. This could be associated with increased volatility of the extractive (low molecular weight compounds) and hemicelluloses in the material, which probably results in reduced temperatures corresponding to the degradation of components such as hemicellulose and lignin, because degradation of one component in the 
material may accelerate the degradation of the others [19]. Likewise, the low degradation temperature in the nests of $M$. imitator, $P$. apicalis and $A$. multipicta can lead to undesirable properties such as browning and decreased mechanical resistance when subjected to temperatures above $200^{\circ} \mathrm{C}$. The degradation of one component in the material can accelerate the degradation of the others [19], and the low degradation temperature in the nests of M. imitator, $P$. apicalis and A. multipicta can lead to undesirable properties such as browning and decreased mechanical resistance when subjected to temperatures above $200^{\circ} \mathrm{C}$.
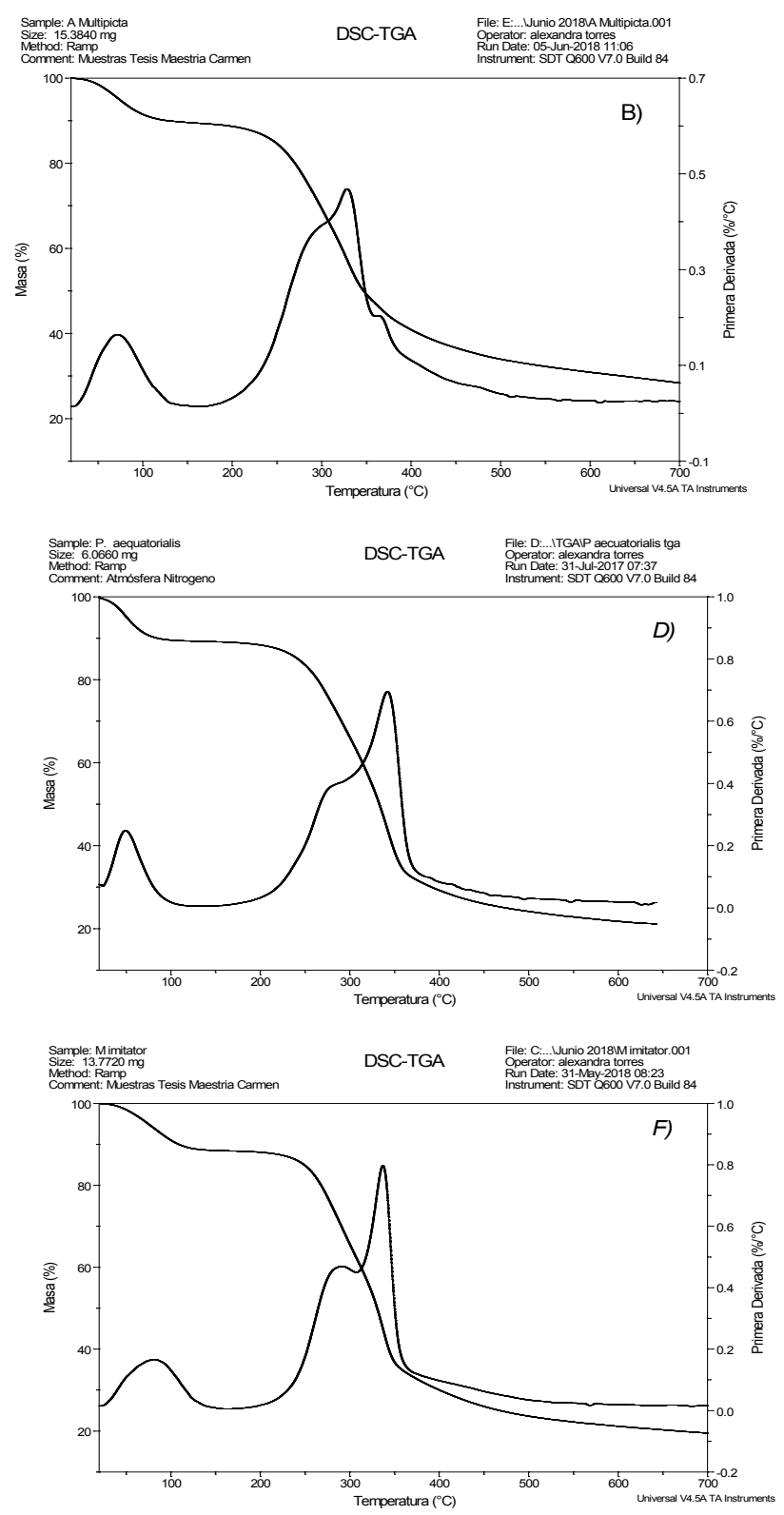
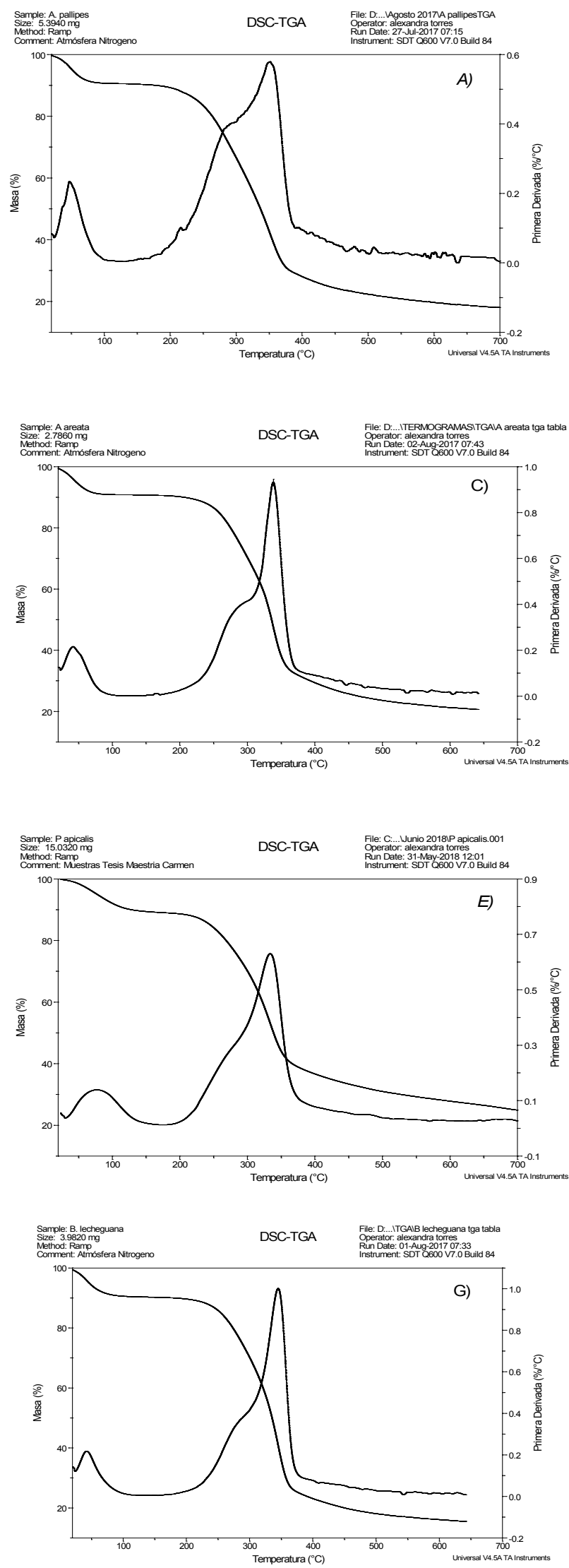

Figure 1. TGA and DTG curves for the nests of the wasp species studied. A) A. pallipes, B) A. multipicta, C) A. areata, D) P. aequatorialis, E) P. apicalis, F) M. imitator, G) B. lecheguana

Source: Author 


\section{Differential scanning calorimetry (DSC)}

Table II shows the results obtained by differential scanning calorimetry. The corresponding thermographs are presented in Figure 2. The thermographs show between 4 and 5 transitions. The first transition corresponds to a large endothermic peak in the temperature range of $54.97 \pm 2.34^{\circ} \mathrm{C}$ - $69.18 \pm 3.45^{\circ} \mathrm{C}$, attributed to the elimination of moisture when the sample is heated. content in these nests [25]. Cellulose enthalpy is also higher in B. lecheguana and A. pallipes compared to the nests of the other species. This is due to the fact that the cellulose chains organized in the nests of these two species can increase the thermal stability of the material even when the degradation temperatures of the extractive content are high (Table 4), since it is necessary to supply more energy to melt the cellulose crystals which increases their enthalpy.

Table II. Maximium Temperatures and Enthalpy of Cellulose Obtained From the DSC Curves

\begin{tabular}{|c|c|c|c|c|c|c|c|c|c|c|}
\hline specie & $\begin{array}{l}\mathrm{T}_{\text {picol }} \\
\left({ }^{\circ} \mathrm{C}\right)\end{array}$ & $\Delta \mathrm{H}(\mathrm{J} / \mathrm{g})$ & $\begin{array}{l}\mathrm{T}_{\text {pico2 }} \\
\left({ }^{\circ} \mathrm{C}\right)\end{array}$ & $\Delta \mathrm{H}(\mathrm{J} / \mathrm{g})$ & $\begin{array}{l}\mathrm{T}_{\text {pico3 }} \\
\left({ }^{\circ} \mathrm{C}\right)\end{array}$ & $\Delta \mathrm{H}(\mathrm{J} / \mathrm{g})$ & $\begin{array}{l}\mathrm{T}_{\text {pico4 }} \\
\left({ }^{\circ} \mathrm{C}\right)\end{array}$ & $\Delta \mathrm{H}(\mathrm{J} / \mathrm{g})$ & $\begin{array}{l}\mathrm{T}_{\text {picos }} \\
\left({ }^{\circ} \mathrm{C}\right)\end{array}$ & $\Delta \mathrm{H}(\mathrm{J} / \mathrm{g})$ \\
\hline A.pallipes & $59.73 \pm 2,09$ & $84.32 \pm 3,45$ & $200.44 \pm 2,34$ & $133.24 \pm 0,87$ & $353.95 \pm 4,32$ & $58.79 \pm 0,76$ & $416.36 \pm 1,23$ & $41.86 \pm 0,98$ & $510.71 \pm 0,26$ & $82.00 \pm 8,09$ \\
\hline A. multipicta & $63.81 \pm 3,67$ & $74.82 \pm 2,34$ & $200.56 \pm 3,24$ & $133.80 \pm 6,83$ & $316.52 \pm 2,34$ & $38.06 \pm 6,45$ & $395.22 \pm 3,45$ & $65.62 \pm 3,90$ & $524.08 \pm 2,34$ & $123.7 \pm 7,65$ \\
\hline A. areata & $59.97 \pm 4,01$ & $75.57 \pm 10,23$ & $200.40 \pm 9,76$ & $174.62 \pm 0,86$ & $340.42 \pm 2,34$ & $48.74 \pm 3,08$ & $451.21 \pm 0,76$ & $41,86 \pm 3,76$ & -- & -- \\
\hline P. aequatorialis & $61.29 \pm 5,46$ & $82.98 \pm 3,54$ & $200.44 \pm 6,76$ & $147.80 \pm 5,43$ & $343.76 \pm 3,09$ & $50.29 \pm 0,87$ & $393.63 \pm 2,65$ & $57.24 \pm 3,76$ & $491.24 \pm 3,23$ & $77.79 \pm 9,87$ \\
\hline P. apicalis & $69.18 \pm 3,45$ & $90.35 \pm 3,45$ & $200.79 \pm 3,98$ & $136.23 \pm 2,87$ & $317.53 \pm 1,24$ & $27.04 \pm 31,32$ & $415.93 \pm 1,23$ & $38.11 \pm 2,34$ & -- & -- \\
\hline M. imitator & $64.06 \pm 1,09$ & $88.56 \pm 34,12$ & $200.43 \pm 5,09$ & $138.61 \pm 6,87$ & $309.98 \pm 1,54$ & $22.88 \pm 2,08$ & $433.53 \pm 2,34$ & $37.93 \pm 4,32$ & $542.93 \pm 4,56$ & $87.06 \pm 5,87$ \\
\hline B. lecheguana & $54.97 \pm 2,34$ & $86.95 \pm 9,81$ & $200.40 \pm 0,87$ & $137.23 \pm 0,87$ & $358.63 \pm 2,34$ & $59.95 \pm 9,08$ & $440.99 \pm 3,34$ & $42.99 \pm 2,12$ & $479.02 \pm 1,09$ & $73.14 \pm 2,76$ \\
\hline
\end{tabular}

corresponds to non-quantifiable transitions and enthalpies in the different samples

The second transition is endothermic and is related to the degradation of hemicelluloses in the range between $200.40 \pm 0.87^{\circ} \mathrm{C}-200.79 \pm 3.98^{\circ} \mathrm{C}$ and similar values were found in the nests of the wasp species studied. The third transition is endothermic in a range between $309.98 \pm 1.54^{\circ} \mathrm{C}-358.63 \pm 2.34^{\circ} \mathrm{C}$, related to the cellulose fraction, for this transition is included the enthalpy related to the degradation of the crystalline part of the cellulose for the nests of the species studied. Finally, there are two exothermic transitions, one of them between $393.63 \pm 2.65^{\circ} \mathrm{C}$ $451.21 \pm 0.76^{\circ} \mathrm{C}$ assigned to lignin decomposition, present in all the species studied. The other transition is between $479.02 \pm 1.09^{\circ} \mathrm{C}-542.93 \pm 4.56^{\circ} \mathrm{C}$; according to other studies, this transition has been related to the formation of gaseous products released during the pyrolysis process experienced by the samples.

The nests of $B$. lecheguana and A. pallipes had the highest temperatures associated with cellulose degradation (Table II). Behavior that may be associated with the higher crystalline cellulose
Currently, in the scientific literature, few studies of thermal analysis in materials designed by social insects are reported, especially in wasp construction material. The study reported by Erik Schmolz [26], corroborates the results obtained in this study. On the other hand, considering that wasp nests are built using worn wood fibers, it is possible to make comparisons with other studies related to thermal analysis in wood, finding thermal behavior similar to the results obtained in the nests of the wasp species evaluated in this study [19], [27] - [29].

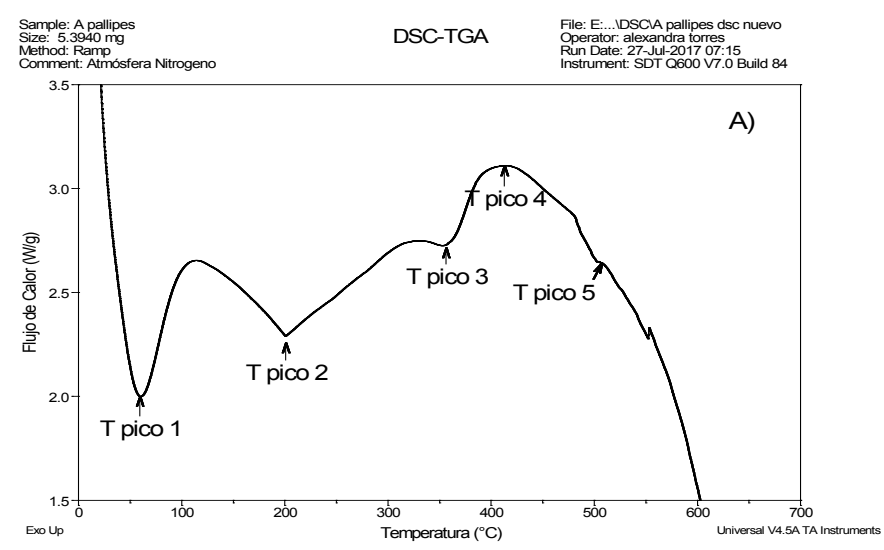


Chemical and thermal characterization of the construction material of nests of seven species of wasps from Norte de Santander - Colombia
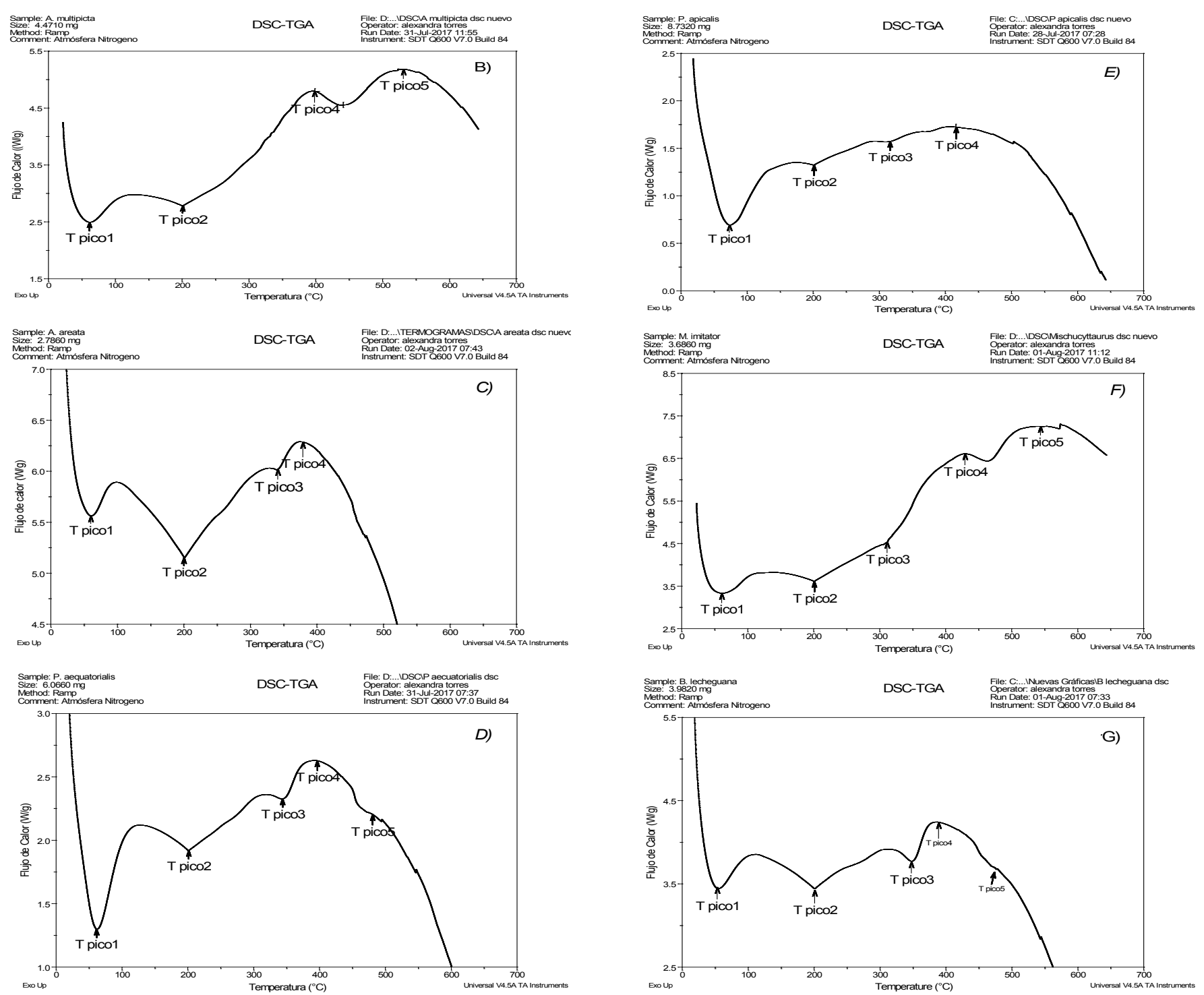

Figure 2. DSC curves for the nests of the wasp species studied. A) A. pallipes, B) A. multipicta, C) A. areata, D) P. aequatorialis, E) P. apicalis, F) M. imitator, G) B. lecheguana Source: Author

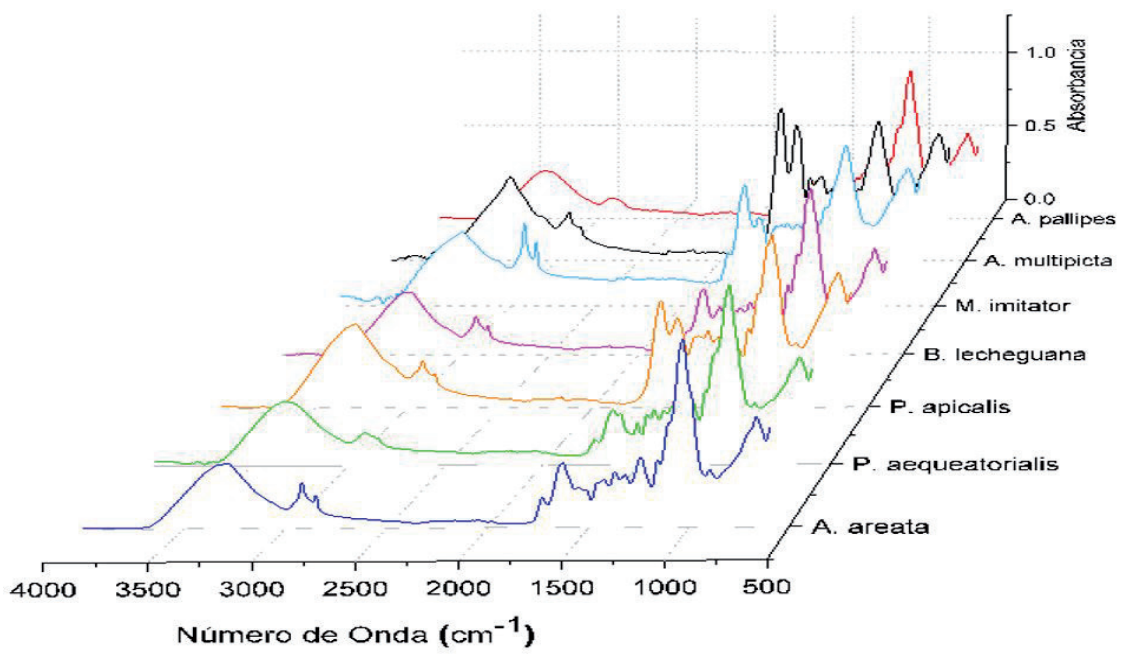

Figure 3. FTIR-ATR spectra of nest samples of different species.

Source: Author 


\section{FTIR-ATR Spectroscopy}

The IR spectra for the nest samples of the seven wasp species can be seen in Figure 3.

Table III lists the respective identification of the different IR bands in the samples studied; it is possible to observe the presence of bands assigned to vibrational modes characteristic of methyl, methylene, hydroxyl groups characteristic of cellulose, hemicellulose and present in many groups of lignin and carbohydrates [25], [30], [31].

\section{$X$-ray fluorescence - XRF}

Table IV shows the concentration of the metals found in the samples. The species $\mathrm{A}$. areata records the highest values in the metals $\mathrm{K}, \mathrm{Ca}, \mathrm{Al}, \mathrm{Mg}, \mathrm{Ti}, \mathrm{Cr}$,
$\mathrm{Mn}, \mathrm{Fe}, \mathrm{Ni}, \mathrm{Zn}$ and $\mathrm{Li}$ except for $\mathrm{Cu}$ metal in which intermediate values are recorded in comparison with the other species. While in the nests of the species $B$. lecheguana low values are registered in the concentration of the metals $\mathrm{Ca}$, $\mathrm{Mg}, \mathrm{Ti}, \mathrm{Cr}, \mathrm{Mn}$ and $\mathrm{Cu}$, with respect to the other species of wasps. The metals $\mathrm{Fe}, \mathrm{Ca}$ and $\mathrm{Mg}$ determined coincide with those found in other studies, affirming that the material can offer very promising applications in adsorption studies, [32] other authors affirm that the composition of the material is quite different from one species to another, and report that the most important components in the nests are: $\mathrm{Ca}, \mathrm{Si}, \mathrm{Al}, \mathrm{Mg}$ and $\mathrm{K}$, this coincides with the results obtained in this study, although the metal found in greater quantity was iron [2], [23].

Table III. Identification of Functional Groups in the IR Spectra of the Samples

\begin{tabular}{|c|c|c|c|c|c|c|c|c|}
\hline Type of link & $\begin{array}{l}\text { Wave num- } \\
\text { ber }\left(\mathrm{cm}^{-1}\right)\end{array}$ & A. areata & A. multipicta & A. pallipes & B. lecheguana & M. imitator & P. aequatorialis & P. apicalis \\
\hline $\begin{array}{c}\text { O-H } \\
\text { (Celulosa) }\end{array}$ & $3276-3575$ & 3281 & 3276 & 3337 & 3284 & 3284 & 3331 & 3277 \\
\hline C-H & $2917-2940$ & 2918 & 2923 & 2922 & 2917 & 2919 & 2925 & 2919 \\
\hline$-\mathrm{CH}_{2}$ & $2850-2870$ & 2851 & 2852 & 2864 & 2852 & 2851 & 2851 & 2852 \\
\hline $\begin{array}{c}\mathrm{C}=\mathrm{O} \\
\text { (Carbonilo) }\end{array}$ & $1728-1735$ & 1730 & -- & 1728 & 1728 & 1728 & 1728 & -- \\
\hline $\mathrm{C}=\mathbf{O}$ & $1612-1643$ & 1627 & 1629 & 1630 & 1630 & 1627 & 1631 & 1628 \\
\hline $\begin{array}{c}\text { C-C } \\
\text { (Lignina) }\end{array}$ & $1590-1600$ & -- & -- & 1594 & -- & -- & 1594 & -- \\
\hline $\mathrm{N}-\mathrm{H}$ & $1530-1559$ & 1547 & 1538 & -- & 1542 & 1543 & 1546 & 1542 \\
\hline $\begin{array}{c}\mathrm{C}=\mathrm{C} \\
\text { (Lignina) }\end{array}$ & $1504-1510$ & 1510 & -- & 1505 & -- & -- & 1507 & -- \\
\hline $\mathrm{CH}_{2}$ & $1450-1460$ & 1454 & 1452 & 1456 & 1453 & 1442 & 1456 & 1444 \\
\hline $\mathrm{CH}$ & $1418-1425$ & 1424 & -- & 1423 & 1423 & 1420 & 1420 & 1424 \\
\hline $\begin{array}{c}\mathrm{C}-\mathrm{CH}_{3} \\
\begin{array}{c}\text { (Lignina - Carbo- } \\
\text { hidratos) }\end{array}\end{array}$ & $1365-1375$ & 1367 & 1375 & 1369 & 1370 & 1375 & 1371 & 1374 \\
\hline $\mathrm{CH}_{2}$ & $1315-1324$ & 1317 & 1315 & 1323 & 1314 & 1320 & 1323 & 1315 \\
\hline $\begin{array}{c}\mathrm{C}-\mathrm{O}, \mathrm{C}=\mathrm{O}, \\
\mathrm{C}-\mathrm{C}\end{array}$ & $1233-1243$ & 1241 & 1238 & 1233 & 1237 & 1236 & 1234 & 1241 \\
\hline$-\mathrm{OH}$ & $1200-1210$ & -- & -- & -- & 1204 & -- & -- & 1205 \\
\hline $\begin{array}{c}\text { C-O-C } \\
\text { (Celulosa) }\end{array}$ & $1145-1165$ & 1155 & 1158 & 1155 & 1155 & 1150 & 1153 & 1156 \\
\hline $\begin{array}{c}\text { O-H } \\
\text { (Celulosa) }\end{array}$ & $1104-1110$ & 1105 & -- & 1106 & 1104 & -- & 1104 & 1104 \\
\hline C-O & $1030-1060$ & 1031 & 1035 & 1030 & 1030 & 1030 & 1035 & 1035 \\
\hline $\begin{array}{c}\text { C-H } \\
\begin{array}{c}\text { (Celulosa - hemi- } \\
\text { celulosa) }\end{array}\end{array}$ & $890-899$ & 897 & 893 & 894 & 896 & 894 & 894 & 896 \\
\hline C-H & $660-669$ & 663 & 665 & 666 & 664 & 664 & 662 & 666 \\
\hline
\end{tabular}

corresponds to the absorption bands not found in the different samples. 
Table IV. Elemental Composition of Wasp Nest Samples

\begin{tabular}{|c|c|c|c|c|c|c|c|}
\hline \multirow[b]{2}{*}{ Element } & \multicolumn{7}{|c|}{ Concentration (mg/kg) } \\
\hline & A. pallipes & A. multipicta & A. areata & P. aequatorialis & P. apicalis & M. imitator & B. lecheguana \\
\hline $\mathrm{K}$ & $189,5 \pm 0,5$ & $266,3 \pm 0,3$ & $305,3 \pm 0,2$ & $186,7 \pm 0,3$ & $247,0 \pm 0,2$ & $256,5 \pm 0,6$ & $253,5 \pm 0,5$ \\
\hline $\mathrm{Ca}$ & $125,2 \pm 0,3$ & $228,9 \pm 0,2$ & $265,3 \pm 0,3$ & $243,9 \pm 0,3$ & $238,7 \pm 0,1$ & $137,2 \pm 0,4$ & $97,6 \pm 0,2$ \\
\hline $\mathrm{Al}$ & $399,5 \pm 0,3$ & $809,3 \pm 0,2$ & $965,4 \pm 0,3$ & $977,6 \pm 0,3$ & $780,8 \pm 0,4$ & $566,6 \pm 0,2$ & $476,6 \pm 0,2$ \\
\hline $\mathrm{Mg}$ & $221,6 \pm 0,2$ & $342,7 \pm 0,1$ & $406,6 \pm 0,2$ & $349,6 \pm 0,2$ & $407,8 \pm 0,3$ & $231,6 \pm 0,3$ & $221,6 \pm 0,2$ \\
\hline $\mathrm{Ti}$ & $38,5 \pm 0,2$ & $61,6 \pm 0,3$ & $78,4 \pm 0,1$ & $47,5 \pm 0,3$ & $58,2 \pm 0,3$ & $38,5 \pm 0,2$ & $27,3 \pm 0,1$ \\
\hline $\mathrm{Cr}$ & $5,67 \pm 0,01$ & $15,8 \pm 0,2$ & $17,5 \pm 0,3$ & $15,34 \pm 0,04$ & $14,7 \pm 0,2$ & $5,67 \pm 0,01$ & $4,98 \pm 0,03$ \\
\hline $\mathrm{Mn}$ & $2,09 \pm 0,03$ & $4,23 \pm 0,03$ & $6,78 \pm 0,05$ & $5,16 \pm 0,02$ & $4,32 \pm 0,04$ & $2,09 \pm 0,03$ & $1,89 \pm 0,02$ \\
\hline $\mathrm{Fe}$ & $1009,5 \pm 0,7$ & $1735 \pm 1$ & $2635 \pm 1$ & $1390 \pm 1$ & $1420 \pm 1$ & $1070,5 \pm 0,7$ & $1099,7 \pm 0,3$ \\
\hline $\mathrm{Ni}$ & $11,8 \pm 0,4$ & $15,8 \pm 0,1$ & $16,9 \pm 0,2$ & $21,6 \pm 0,3$ & $14,7 \pm 0,2$ & $12,8 \pm 0,4$ & $9,56 \pm 0,06$ \\
\hline $\mathrm{Cu}$ & $13,4 \pm 0,6$ & $27,5 \pm 0,4$ & $13,9 \pm 0,2$ & $27,6 \pm 0,5$ & $25,0 \pm 0,5$ & $15,4 \pm 0,6$ & $12,7 \pm 0,3$ \\
\hline $\mathrm{Zn}$ & $26,9 \pm 0,4$ & $104,3 \pm 0,2$ & $145,8 \pm 0,1$ & $102,7 \pm 0,3$ & $98,6 \pm 0,3$ & $56,9 \pm 0,4$ & $37,8 \pm 0,2$ \\
\hline $\mathrm{Se}$ & --- & --- & --- & $1,4 \pm 0,2$ & $5,4 \pm 0,2$ & --- & --- \\
\hline $\mathrm{Li}$ & --- & $12,2 \pm 0,3$ & $17,9 \pm 0,2$ & $5,9 \pm 0,7$ & $3,9 \pm 0,4$ & $2,3 \pm 0,4$ & --- \\
\hline
\end{tabular}

\section{Conclusions}

The characteristic bands of the compounds, in the FTIR spectra of the nests of the different species, exhibit the presence of hemicellulose, cellulose and lignin, as well as aliphatic and aromatic hydrocarbons, alcohols, phenols, ketones and aliphatic acids.

Through X-ray fluorescence (XRF) were found in all samples mostly iron and aluminum, results that differ from that reported for nests of species not found in Colombia, which contain more calcium and potassium.

Thermogravimetric analysis showed that the nest samples of the analyzed species A. pallipes, $A$. multipicta, A. areata, $P$. aequatorialis, $P$. apicalis, $M$. imitator and B. lecheguana, presented four losses of mass, the first of these $(50.32 \pm 0.84-87.45 \pm$ $6.74{ }^{\circ} \mathrm{C}$ ) attributed to the loss of water in the form of moisture absorbed in the surface of the nest; In addition to this there are three other processes, the first $\left(200,39 \pm 2,34{ }^{\circ} \mathrm{C}-238,58 \pm 1,80{ }^{\circ} \mathrm{C}\right)$ attributed to the decomposition of hemicelluloses, the second process $\left(274,10 \pm 4,65{ }^{\circ} \mathrm{C}-307,39 \pm 1,23{ }^{\circ} \mathrm{C}\right)$ associated with cellulose degradation and the third process $\left(323,22 \pm 0,34{ }^{\circ} \mathrm{C}-350,95 \pm 8,15{ }^{\circ} \mathrm{C}\right)$ corresponding to lignin degradation.

By thermal analysis, it is found that the nests of the species M. imitator, $P$. apicalis and A. multipicta have less thermal stability compared to the samples of the other species, and the building material of these species is characterized by starting the degradation process at relatively lower temperatures, which causes a reduction in thermal stability. Behavior that is probably associated with a greater volatility of the extracts (low molecular weight compounds).

The results of the different analyses indicate that there are variables of structure, composition and thermal behaviour that differ significantly in the nests regardless of the species, genus or place of origin of the samples.

\section{Acknowledgements}

The authors thank the University of Pamplona for its economic support during the execution of this work, Dr. Orlando Tobias Silveira who carried out the taxonomic identification of the specimens up to the species level, Zootechnist Wolfgang Hoffmann who identified the specimens up to the genus level, located and collected the nests; and Magister José Quintana for his participation in the execution of the $\mathrm{XRD}$ and XRF analyses.

\section{References}

[1] B. M. Dress and J. Jackman, "Field Guide to Texas Insect. Mud Daubers", Gulf Publishing Company, 1999. [Online]. Available: http:// texasinsects.tamu.edu/cimg334.html

[2] F. Perveen and M. Shah, "Nest architectural patterns by three wasp species (Vespa Velutina, Polistes flavus and Sceliphron formosum) with reference to their behavior", International 
Journal of Tropical Insect Science, vol. 5, pp. $1-8,2013$.

[3] C. A. Triplehorn, D. J. Borror and N. F. Johnson, "Borror and DeLong's introduction to the study of insects", Brooks/Col. Belmont, CA, 2006.

[4] C. Barthelemy, "A new record for Hong Kong and China of a Polistine wasp of the genus Ropalidia: Ropalidia mathematica (Vespidae: Polistinae: Ropalidiini)", Porcupine, vol. 2006, no. 34 pp. 8-10, 1999.

[5] J. Carpenter and O. Marques, "Contribuição ao estudo de vespídeos do Brasil (Insecta, Hymenoptera, Vespoidea, Vespidae)", Série Publicações digitais, vol. 2, no. 1, 2001

[6] F. Prezoto and M. Clemente, "Vespas Sociais do Parque Estadual do Ibitipoca, Minas Gerais, Brazil", MG Biota, vol. 3, no. 4, pp. 22-32, 2010.

[7] M. Shah, M. Khan, M. Rafi, S. Mehmood and M. Farooq, "Nesting biology and Social behaviour of Paper wasp (Polistes flavus) and Honey bee (Apis mellifera) in District Mansehra, Pakistan", International Journal of Biosciences, vol. 3, no. 2, pp. 80-86, 2013.

[8] M. R. Myerscough and B. P. Oldroyd, "Simulation models of the role of genetic variability in social insect task", Insectes Sociaux, vol. 51, no. 2004, pp. 146-152, 2006.

[9] G. Theraulaz and E. Bonabeau, "Coordination in distributed building”, Science, vol. 269, no. 5224, pp. 686-688, 1995.

[10] S. A. Khan, M. A. Aqueel, M. Ahmad and M. Munawar, "Relative preference of wood by Polistes flavus L. for Nest building", Journal of Entomology and Zoology Studies, vol. 3, no. 3, pp. 408-410, 2015.

[11] B. Clapperton and P. Lo, "Nesting biology of Asian paper wasps Polistes chinensis antennalis Perez, and Australian paper wasps Polistes humilis (Fabricius) (Hymenoptera,
Vespidae) in northern New Zealand", New Zealand Journal of Zoology, vol. 27, pp. 189-195, 2000.

[12] S. Titotto, D. Oliveira and A. Ferrante, "Space and energy: Relationships among architects from nature", SCIentific RESearch and Information Technology, vol. 5, no. 1, pp. 115-120, 2015.

[13] Y. López, S. Canchila and D. Alvarez, "Listado de avispas sociales (Vespidae: Polistinae) del departamento de Sucre, Colombia", Biota Colombiana, vol. 14, no. 2, pp. 108-113, 2013.

[14] School of Life Sciences, Ed., "Social biomimicry. Insect Societies and Human Design", in The Third Annual Frontiers in Life Sciences Conference, pp. 22-35, 2010.

[15] J. F. Vincent, "Defense and attack strategies and mechanisms in biology Biomimetics", in Biologically Inspired Technologies, pp. 341-63, 2005.

[16] A. Dunster, "Naturally innovative : A briefing paper for the construction industry", editado por Sami Mahroum, Yasser Al-Saleh, 2007.

[17] C. Kamalu, M. Nwakaudu, O. Nkuzinna, F. Uzondu, E. Effiong and J. Obibuenyi, "Chemical composition of the nest and models of the metamophic polymorphism of the Mud Dauber wasp", JACSON-Applied Chemical Science, vol. 3, no. 2328-2827, pp. 1-14, 2015.

[18] A. Lateef, M. Akande, A. Sunday, F. Bolaji, E. Gueguim-Kana and L. Beukes, "Paper wasp nest-mediated biosynthesis of silver nanoparticles for antimicrobial, catalytic, anticoagulant, and thrombolytic applications", 3 Biotech, vol. 6, no. 2, pp. 140, 2016.

[19] M. Poletto, "Thermal degradation and morphological aspects of four wood species used in lumber industry", Revista Árvore, vol. 40, no. 5, pp. 941-948, 2016. 
[20] R. Torres, “Análise do perfil químico de ninhos de vespas do gênero Polistes (Hymenoptera : Vespidae)", Universidade Federal da Grande Dourados, pp. 98, 2015.

[21] M. Cole, M. Hansell and C. Seath, "A quantitative study of the physical properties of nest paper in three species of Vespine wasps (Hymenoptera, Vespidae)", Insectes Sociaux, vol. 48, no. 1, pp. 33-39, 2001.

[22] K. Kudo et al., "Nest materials and some chemical characteristics of nests of a New World swarm-founding polistine wasp, Polybia paulista (Hymenoptera Vespidae)", Ethology Ecology \& Evolution, vol. 13, no. november, pp. 351-360, 2001.

[23] K. Khan, M. Rasool, M. Zahid and M. Ismail, "Chemical Composition, Structure and Architecture of the Nest of Various Species of Vespidae (Insecta: Hymenoptera)", Jokull Journal, vol. 68, no. 3, pp. 1-14, 2018.

[24] W. Etges and M. Ahrens, "Premating isolation is determined by larval rearing substrates in cactophilic Drosophila mojavensis. V. Deep geographic variation in epicuticular hydrocarbons among isolated populations", The American Naturalist, vol. 158, pp. 585-598, 2001.

[25] M. P. Poletto, A. J. Zattera and R. M. Santana, "Structural differences between wood species: Evidence from chemical composition, FTIR spectroscopy, and thermogravimetric analysis", The Journal of Applied Polymer Science, vol. 126, pp. 336-343, 2012.

[26] E. Schmolz, N. Bruders, R. Daum and I. Lamprecht, "Thermoanalytical investigations on paper covers of social wasps", Thermochimica Acta, vol. 361, no. 1-2, pp. 121-129, 2000.

[27] K. Werner, L. Pommer and M. Broström, "Thermal decomposition of hemicelluloses", Journal of Analytical and Applied Pyrolysis, vol. 110, no. 1, pp. 130-137, 2014.
[28] A. Carneiro et al., "Estudo Da Decomposição Térmica Da Madeira De Oito Espécies Da Região Do Seridó, Rio Grande Do Norte", Revista Árvore, vol. 37, no. 6, pp. 1153-1163, 2013.

[29] B. Pereira, A. Carneiro, A. Carvalho, P. Trugilho, I. Melo and A. Oliveira, "Study Of Thermal Degradation Of Eucalyptus Wood By Thermogravimetry And Calorimetry", Revista Árvore, vol. 37, no. 3, pp. 567-576, 2013.

[30] M. Poletto, H. Ornaghi Júnior and A. Zattera, "Native Cellulose: Structure, Characterization and Thermal Properties", Materials (Basel), vol. 7, pp. 6105-6119, 2014.

[31] Y. Lu, S. Xiao, R. Gao, J. Li and Q. Sun, "Improved weathering performance and wettability of wood protected by $\mathrm{CeO} 2$ coating deposited onto the surface", Holzforschung, vol. 68, no. 3, pp. 345-351, 2014.

[32] P. Adie, D. Kukwa, R. Ikyereve and P. D. Kungur, "Physicochemical Characterization of Hymenopterasphecidae (mud-wasp) nest", Journal of Chemical Sciences, vol. 3, no. 10, pp. 1-7, 2013. 